DOI: https://doi.org/10.34069/AI/2022.49.01.16

How to Cite:

Lutska, G., Karmaza, O., Koucherets, D., Makhinchuk, V., \& Koroied, S. (2022). The analysis of the implementation of inheritance law in selected EU countries. Amazonia Investiga, 11(49), 149-155. https://doi.org/10.34069/AI/2022.49.01.16

\title{
The analysis of the implementation of inheritance law in selected EU countries
}

\section{Аналіз реалізації спадкового права окремих країн СС}

Received: December 1, 2021

Accepted: January 19, 2022

\author{
Written by: \\ Lutska Galyna $^{59}$ \\ https://orcid.org/0000-0001-5840-0603 \\ Karmaza Oleksandra ${ }^{60}$ \\ https://orcid.org/0000-0003-4895-5220 \\ Koucherets Daria ${ }^{61}$ \\ https://orcid.org/0000-0001-7935-1038 \\ Makhinchuk Vitalii ${ }^{2}$ \\ https://orcid.org/0000-0003-4360-0287 \\ Koroied Sergii ${ }^{63}$ \\ https://orcid.org/0000-0001-7899-957X
}

\begin{abstract}
The purpose of the article is to analyze the peculiarities of the inheritance procedure of individual European countries. The subject of the study is the implementation of inheritance law in Spain, Germany and Austria. The research methodology includes the use of general scientific and special methods of scientific cognition: dialectical, historical and legal, formal and logical, method of hermeneutics, generalization, comparison, etc. Research results. The procedures for implementation of the right to inheritance in Spain, Germany and Austria are considered. The forms and features of making wills in these countries are studied. The cases of acceptance and rejection of inheritance are analyzed. The right of minors to make a will is covered.. The practical implication lies in the possibility of applying international norms in the legislation of Ukraine. Value / originality. The Authors' proposals on the implementation of European experience in the inheritance legislation of Ukraine are given.
\end{abstract}

Key words: heir, inheritance, testament, testator, will.

\begin{abstract}
Анотація
Метою статті $є$ аналіз особливостей процедури спадкування окремих європейських країн. Предметом дослідження є реалізація спадкового права в Іспанії, Німеччині та Австрії. Методологія дослідження включає в себе використання загальнонаукових та спеціальних методів наукового пізнання: діалектичний, історико-правовий, формально-логічний, метод герменевтики, узагальнення, порівняння тощо. Результати дослідження. Розглянуто порядок реалізації права на спадок у Іспанії, Німеччині та Австрії. Визначено форми та особливості складання заповітів у цих країнах. Проаналізовано випадки прийняття та відмови від спадщини. Висвітлено право неповнолітніх осіб на складення заповіту. Практичне значення полягає у можливості застосування міжнародних норм у законодавстві України. Цінність/оригінальність. Наведено пропозиції авторів щодо впровадження європейського досвіду у спадкове законодавство України.
\end{abstract}

Ключові слова: спадкування, заповіт, спадкоємець, спадкодавець

\footnotetext{
${ }^{59}$ Doctor of Juridical Sciences, Associate Professor, Professor at the Department of Law of Higher Education Institution "King Danylo University", Ukraine.

${ }^{60}$ Doctor of Juridical Sciences, Professor, Professor of the Institute of Law of Taras Shevchenko National University of Kyiv, Ukraine.

${ }^{61}$ Doctor of Juridical Sciences, Professor, Rector of University of Artificial Intelligence and Digitalization, Ukraine.

${ }^{62}$ Doctor of Juridical Sciences, Professor, Deputy Director of the Institute for Research of the F.G. Burchak Scientific-Research Institute of Private Law and Business of National Academy of Law Sciences of Ukraine, Ukraine.

${ }^{63}$ Doctor of Juridical Sciences, Professor. Professor at the Department of Law of Higher Education Institution "King Danylo University", Ukraine.
} 


\section{Introduction}

The inheritance institution in the civil law of any legal system is closely related to all other types of property rights. After the death of a person, property, which is based on property rights and other property rights, often remains. They are subject to inheritance upon the death of the owner. The question of what remains after the death of the deceased owner, to whom it should be transferred, in what order and to what extent is in the focus of attention of society and the State from ancient times to the present.

It should be noted that Roman private law is the foundation of modern inheritance law. All the basic ideas, concepts and principles originate from it. The first research related to the study of inheritance law appeared in the early 50's in domestic science, but its boundaries were very narrow, given the period of new economic policy at the time. The Civil Code of the USSR of 1963 revealed the concept of a will, strengthened the role of family ties in inheritance, but did not regulate the concept of inheritance. Instead, considerable attention was paid to inheritance by will and law, which are still relevant today.

The adoption of the Civil Code of Ukraine in 2003 was the impetus for the development of the doctrine of inheritance law. It was believed that the civil code of any State reflects its values, on which the future is built.

At present, in the context of rapid economic recovery, ensuring public access to quality and fast-track public services, and taking into account the European aspirations of our country, which is guided by international experience in hereditary law, we consider it necessary to analyze the legal consolidation and regulation of inheritance in some EU countries.

\section{Methodology}

The methodology of the article is based on general and special methods of scientific knowledge, the use of which is determined by the purpose, object, and subject of research.

The method of hermeneutics is used in the process of studying the texts of foreign legislative acts and research materials.

The application of historical and legal method allows to trace the historical development of the studied phenomenon in European countries.
With the help of formal and logical (dogmatic) method the norms of civil law and practice of their application in such countries as Spain, Germany and Austria are analyzed.

The method of summarization is applied to the draw relevant conclusions and suggestions.

\section{Literature Review}

The development and implementation of inheritance law is the subject of research by many domestic scholars. Thus, Kukhariev (2020) considered in his dissertation "Discretion within Inheritance Law" the concept of discretion, which aims to improve the legal regulation of inheritance relations. As the result, basic models of hereditary discretion were established, which are the forms of expression of legal freedom in the area of inheritance.

Valakh (2009) conducted a classification of legal facts that cause the dynamics of inheritance, identified legal facts that lead to the termination of the inheritance. Besides, the researcher distinguished between model and specific (individual) hereditary legal relations.

Fedorych (2018) analyzed the ways of exercising the right to inheritance, which are realized by concluding a unilateral agreement by the heir in the work "Exercise of the right to inheritance under the civil legislation of Ukraine". The researcher also formulated the concepts of "right to inherit" and "exercise of the right to inherit".

Zavgorodnia qualified disputes arising from hereditary legal relations in her study "Court proceedings in disputes arising from inheritance" (2016), in which the problems of proof, presumptions and adjudication of disputes prejudices in disputes arising from hereditary legal relations have been studied.

The work by Alina (2020) also deserves attention. The study clarifies the place of IT objects among the traditional objects of inheritance law. There are also features of digital objects that affect the possibility of their inheritance in the event of the death of the owner. However, the specifics of inheritance law in the countries of the European Union are not fully considered in these works.

The features of Spanish inheritance law are investigated by Wiedermann (2020). She states that it is different from other European nations, 


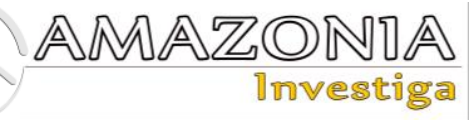

so it is very important to know its aspects. She considers the legal basis for Spanish inheritance law, the process of making will, the property that can be donated and the amount of the tax enshrined.

Elseven (2021) proves that German inheritance law is a complex legal field, made even more challenging in cases involving testators with assets and property abroad. The scholar studies the types of will in this country, statutory succession, the compulsory share of the inheritance and the community of heirs under German law, as well as international inheritance cases and the German inheritance legal system.

Austrian inheritance law has the following features: 1) property located in Austria is always inherited by Austrian rules; 2) the estate is inherited by the heirs if there is no will; 3 ) children and the spouse always have a share in the inheritance; 4) marriage is not the ground for common property ownership; 7) if the child is left without parental supervision, a guardian is appointed to administer his (her) property rights; 8) there is no inheritance tax in Austria (abolished on 1st August 2008) (Marth 2021).

\section{Results and Discussion}

Inheritance law is part of the legal system of each State. It has always been and remains relevant, as it is a sphere of public relations, which to some extent affects each individual. At the same time, inheritance law has always distinguished itself by its conservatism, conditionality of its historical, cultural and religious development, which determines its different legal regulation in each country.

The active development of integration processes necessitates the study of the experience of European countries in addressing issues arising in national legislation.

The inheritance process in Ukraine and the countries of the European Union includes some differences. Therefore, we propose to study the law of succession in such countries as Spain, Germany and Austria.

Spain's inheritance law is part of the Civil Code and determines the further fate of the rights and obligations of an individual after his (her) death. Inheritance in the event of death must first and foremost meet the requirements of legal certainty - it is mandatory to extend the relationship after the death of the owner. These rules are regulated by Section 3 of the Spanish Civil Code, in particular by the Articles 657 - 1087 (Royal Decree No. 206, 1889).

According to Article 667 of the Civil Code of Spain, a will is an act by which a person disposes of all or part of his (her) property after his (her) death. Accordingly, the heritage can include:

- property rights transferred (and not terminated with the death of the testator);

- property obligations that do not end with the death of the debtor;

- intellectual rights retained by a person after his (her) death (copyright).

Personal rights, family rights, public or administrative rights are not included in the inheritance.

The forms of the will, according to Article 676 of the Civil Code of Spain (Royal Decree No. 206, 1889) are: general (común) and special (especial). General one is, in turn, divided into: 1) handwritten; 2) open; 3) closed. Special one is divided into: 1) of a military man; 2) of a seaman; 3) compiled abroad. We suggest to consider some of these forms in more detail.

A will is considered to have been written by hand if the testator made it under the conditions, enshrined by Article 688. Such conditions are: 1) reaching the age established by law (from 14 years; for this form of will - 18 years); 2) handwritten and signed, indicating the date of its compilation; 3) if there are words that have been altered, struck out, rewritten, they should be certified by a signature; 4) foreigners can make such a will in their native language. Besides, the will should be legally certified by a notary (some scientists state that it should be certified by the judge of the court of first instance, so we will use the term "authorized person").

As Sidenko (2017, p. 195) correctly notes, the establishing of such a will has its own peculiarities. Indeed, the person who becomes the owner of the inheritance must, apply to the competent authority (Notario competente) with a will within 10 days after he (she) learned of the testator's death. After making a will and confirming the death of the testator, the authorized person verifies the document for authenticity. This can be done in the presence of three witnesses. If the authorized person concludes that the will is valid, he (she) formally declares its entry into force (Article 693 of the Civil Code of Spain) (Royal Decree No. 206, 1889). 
The open will must be made by the testator personally or orally in the presence of a notary. After that, the notary reads the will aloud, specifying whether everything written is true. This process can be conducted in the presence of witnesses or other persons if desired. After the will is announced, the testator signs it. It is interesting to note that in the event of imminent security or epidemic the testator is unable to make a will. In such cases, five witnesses without a notary and three witnesses without a notary are involved in the procedure, respectively (Articles 700, 701 of the Civil Code of Spain) (Law of Spain 1889).

A private will is written only and must be signed manually. In some cases, there is a requirement to sign every page of the text, including corrections and strikeouts (Article 706 of the Civil Code of Spain) (Royal Decree No. 206, 1889).

Execution of the private will is allowed under the following conditions:

- the document must be in a sealed envelope without any damage;

- the testator is obliged to seal the will or do it in the presence of a notary;

- the testator officially confirms that the envelope he provides to the authorized person contains written (printed) will, executed in accordance with the requirements;

- the notary puts the number and a special seal on the envelope with the will, after which the envelope is signed by athose present;

- after performing all legal actions, the notary transfers the envelope to the testator or a person authorized by him (her).

The person keeping the will must submit it to the authorized judge within 10 days from the date of the testator's death.

The regulation of a will made abroad also deserves attention. Spaniards have the right to make wills outside the country in accordance with the conditions established by the law of the country in which they are. They can also make open and private wills at a diplomatic or consular post. In this case, all the formalities enshrined in Chapters 5 and 6 of the Civil Code of Spain are observed. The diplomatic mission or consular post shall send a copy of the open will or act of execution of the closed will with the signatures and seal to the authorized body of Spain. If the will is kept by an agent of a diplomatic or consular post, he (she) shall transmit it to Spain after the death of the person along with the death certificate. After that, the ministry of foreign affairs (El Ministerio de Estado) publishes information about the death of a person in the newspaper (la Gaceta de Madrid) and all those interested have the opportunity to withdraw the will (Article 736 of the Civil Code of Spain) (Royal Decree No. 206, 1889).

The Spanish Civil Code also enshrines inheritance without a will (De la sucesión intestada) or "by law". Such inheritance is provided for when:

- the person dies without making a will or his (her) will is invalid;

- $\quad$ if the heir is not specified for all or part of the property;

- if the heir does not fulfill the conditions imposed on him (her) or refuses to inherit;

- $\quad$ if the heir cannot inherit.

Besides, if there are no heirs by will, then the property is transferred to the relatives or the State "by law".

It should be noted that the acceptance and renunciation of the inheritance is completely voluntary and has retroactive effect until the death of the person (testator) (Article 988 of the Civil Code of Spain) (Royal Decree No. 206, 1889).

The next country, whose inheritance law we propose to consider, is Germany.

The Constitution of Germany provides for the right of inheritance, the content and scope of which are determined by law. German civil law regulates inheritance relations through established forms of disposition of property after the death of a person. That is, the right of inheritance can be exercised in one of these forms, the most common of which is inheritance by will.

A testament refers to one of the forms of disposition of property along with the inheritance contract (Erbvertragf) in the inheritance law of Germany. According to Article 1922 of the German Civil Code (Introductory Law to the Civil Code, 1994), after the death of a person, his (her) property (inheritance) passes as a whole to one or more heirs. The testator has the right not to determine the heir ( $\mathrm{s}$ ) or to restrict the relatives or one of the spouses in such a right. If there are no heirs (one of the spouses, relatives) by the time the inheritance is opened, then the federal land (last domicile) is the legal heir. If the testator 


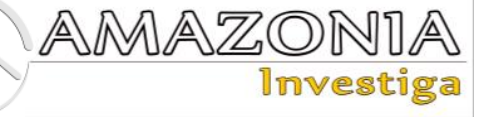

is German, who was not a citizen of any of the federal lands, the inheritance passes to the federal treasury (Article 1936 of the Civil Code of Germany). The inheritance passes to the heir with the right to refuse it. Instead, the federal treasury cannot renounce the inheritance.

Acceptance and refusal of inheritance are also regulated by law. Thus, the heir cannot renounce the inheritance if he (she) has accepted it or the waiver period has expired, but the person can refuse the inheritance by filing an application to the court within 6 weeks from the moment of establishing the fact of the will or the fact of death (Article 1944 of the Civil Code of Germany) (Introductory Law to the Civil Code, 1994).

A minor can also make a will, provided that he / she is 16 years old at the time of making it. The consent of a legal representative or other person is not required in this case.

The Civil Code of Germany provides for two forms of will: 1) notarized (public will); 2) handwritten will.

A public will occurs when the testator announces his last will (orally) in the presence of a notary or sends him (her) a written statement. Such a statement may be transmitted both officially and confidentially.

The text of the handwritten will must be signed by the testator (even if the text itself is printed). The date, time and place must be indicated. Such a will may be transferred for safekeeping to the State agency, of which the testator receives a receipt.

It is also worth noting about the settlement of the extraordinary will (Article 2249 of the Civil Code of Germany) and the sea will (2251 of the Civil Code of Germany) (Introductory Law to the Civil Code, 1994).

The Civil Code of Germany distinguishes common (general) testament (Gemeinschaftliches Testament), which is quite widespread. It can be made only by spouses. That is, the right to create it does not belong to the bride (s) or persons living together.

In 2017, the Law introducing the right to marry for persons of the same sex (Law No. 52, 2017) came into force in Germany. That is, same-sex couples can also make joint will. It is interesting that in the period from 2001 to 2017 , joint will could also be drawn up by persons who are "extramarital partners" (Law of Registered Civil Societies, 2001).

The civil law does not reveal the essence of the joint will, but analyzing this normative act, we can conclude that it has the following features:

1. Composed in a simplified form. If an ordinary will is drawn up with the participation of a notary and in the form of a personal statement (handwritten will), the joint will is made in the form of a selfwritten statement signed by the participants. The time, place and date are also indicated. The will is considered invalid without these attributes. Besides, according to Article 2231 of the Civil Code of Germany (Introductory Law to the Civil Code, 1994), a joint will does not require registration by a notary. Instead, the spouses must submit such a will for safekeeping to the Central Electronic Register of Wills, which has been operating since 2012. After the death of the testator, the notary opens a joint will.

2. It is the "unified act", although the opinions of researchers are divided here. Some scientists believe that the joint will does not always have to be "one and whole", as the will of each spouse may be different. The representatives of another approach believe that a joint will is exclusively a "single act". According to Article 2270 of the Civil Code of Germany (Introductory Law to the Civil Code, 1994), if the spouses have entered a common (interrelated) will into the testament, there can be no question of different orders, as failure or invalidity of one expression of will has similar consequences for another one. Thus, drawing up a joint will, the spouses agree on a common approach to the issues of hereditary succession.

That is, non-reciprocal orders (testamenta reciproca) in a joint will may take place, but alongside mutual ones. For example, one of the spouses determines the other as his (her) heir, even if the latter does not establish such an order.

The set of rights and obligations of the deceased, if they did not arise as a result of legal relations of a purely personal in nature; in Austria it is called the "hereditary estate" or the inheritance of the deceased.

Austrian inheritance law is governed by the Civil Code of Austria (Maslov 2011), in particular Sections by $8-15$, Part Two (Articles $531-$ 824). 
The exclusive right to receive the entire inheritance or a certain part of it is called the right of inheritance (Article 532 of the Civil Code of Austria) (Maslov, 2011). It is a property right that acts against anyone who intends to misappropriate the inheritance.

The right of inheritance is based on: 1) the will of the testator (which is declared in accordance with the law); 2) the inheritance agreement; 3) law. That is, there are three forms (ways) of inheritance. The Code stipulates that these three forms can be carried out jointly (between relatives).

The right of inheritance occurs from the moment of death of the testator. An order by which the testator (in case of his death) transfers his property or part of it to one or more heirs is called the last will of the testator and is one of the forms of inheritance. If the last will (order) of the testator determines the heir, then such a decision is called a will. If it includes other provisions it is called codicilli (codicillus). The Code states that the last will of the individual must be proclaimed free from coercion, deception and influence (Article 565 of the Civil Code of Austria) (Maslov, 2011). The forms of proclamation of the last will are: outside the court, in court, orally, in writing, with or without witnesses.

Minors under the age of 14 are not allowed to declare their last will. Children between the age of 14 and 18 may declare their last will only before a court or notary, except in cases provided for in Article 597 of the Civil Code of Austria when a person is unable to express his (her) will or there are extraordinary circumstances.

Inheritance by law occurs as follows: if the deceased did not leave the last will; if he (she) did not dispose of all his property; if he (she) has not duly notified the persons who are legally entitled to part of the inheritance; if the heirs are unwilling or unable to accept the inheritance. The heirs by law are one of the spouses and those persons who are provided by the queues of inheritance (Article 730). Under Austrian law, there are four such queues.

Proper inheritance is subject to judicial review; the court also carries out the transfer of property. Anyone who wants to inherit must prove in court his (her) legal status, which is provided either by the last will of the testator, or by the testament, or by law. If the court establishes the legal status of the heir, the inheritance is transferred to him (her) and the court proceedings are closed.
Besides, under the contract of inheritance, one of the spouses, who determines the heir independently, may be "bound" by such an order - at the time of death, a quarter of the testator's property should be available for other dispositions (Article 1253 of the Civil Code of Austria). The orders of both spouses are valid only if they mutually identify each other as heirs, or one of spouses. If the heir is the third party, such will may be revoked (Burandt et al., 2019). It should be noted that such an agreement may be concluded only between spouses, already registered partners or engaged (subject to further marriage). In this regard, we can draw a parallel with German law.

\section{Conclusion}

Analyzing the above material, we can conclude that the legal regulation of inheritance in the countries of the European Union is somewhat different, but has one goal - the proper transfer of rights and responsibilities of the person in the event of his death. The conditions for acquiring an inheritance are consideration of this fact (by an authorized person, court, etc.) and transfer of property. It is also important to be able to renounce the inheritance on the grounds established by law. In some cases, the last will of the testator is the prerequisite for the right to inherit.

Thus, inheritance is a legally established transfer of property and individual personal non-property rights and obligations from one person (testator) to another one (heir). The principles of inheritance are: freedom and expression of will of the testator and the heir (s); universality of hereditary succession; sequence; family character; confidentiality of will; protection of hereditary property; reimbursement of expenses, etc.

The study of international experience on the issues of inheritance aims to improve domestic legislation. In particular, the introduction of hereditary will, which is made by minors aged 14 to 18 (on the example of Austria) deserves special attention. Necessary conditions for this act are: written form; date, time, signature of the person; notarization; participation of legal representatives.

Taking into account the experience of Germany, we propose to regulate the issue of restricting the right of one of the spouses to inherit in our country. That is, if one of the spouses (when making a will of the spouses under Article 1243 of the Civil Code of Ukraine) does not want to 


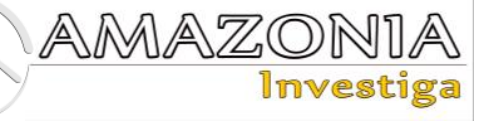

transfer the share of property belonging to him (her) on the right of joint ownership to the other spouse, such property becomes the property of the State. The person should enshrine his (her) will in the testament, regardless of the desire of the other spouse.

\section{Bibliographic references}

Alina, S.S. (2020). Inheritance of IT-objects under modern civil law. - Qualification scientific work, manuscript copyright. (PhD Dissertation). National University "Odessa Law Academy" Ukraine. http://dspace.onua.edu.ua/bitstream/handle/1 1300/12560/\%d0\%94\%d0\%b8\%d1\%81\%d0 $\%$ b5\%d1\%80\%d1\%82\%d0\%b0\%d1\%86\%d $1 \% 96 \% \mathrm{~d} 1 \% 8 \mathrm{f}-$

$\% \mathrm{~d} 0 \% 90 \% \mathrm{~d} 0 \% \mathrm{bb} \% \mathrm{~d} 1 \% 96 \% \mathrm{~d} 0 \%$ bd $\% \mathrm{~d} 0 \% \mathrm{~b}$ 0 .pdf? sequence $=7 \&$ isAllowed $=\mathrm{y}$

Burandt W. et al. (2019). right of inheritance [Erbrecht]. Comment. 3 edition [Kommentar. 3 Auflage]. München: Beck. ISBN 978-3406-72100-7

Elseven, A. (2021). A guide to inheritance and probate in Germany. IamExpat. https://www.iamexpat.de/expat-info/germanexpat-news/guide-inheritance-and-probategermany

Fedorych, I.Y. (2018). Realization of the right to inherit under the civil legislation of Ukraine. (PhD Dissertation). Training and Research Law Institute of Vasyl Stefanyk Precarpathian National University. https://svr.pnu.edu.ua/wpcontent/uploads/sites/5/2018/06/dis_Fedoryc h-1.pdf

Introductory Law to the Civil Code. Introductory Law to the Civil Code in the version published on September 21, 1994 (BGB1. I p. 2494; 1997 I p. 1061). https://www.gesetze-iminternet.de/bgbeg/BJNR006049896.html

Kukhariev, O. Ye. (2020). Discretion within Inheritance Law. (PhD Dissertation). Kharkiv National University of Internal Affairs, Ukraine. http://dspace.univd.edu.ua/xmlui/bitstream/h andle/123456789/9318/aref_Kukhariev_202 0 .pdf? sequence $=1 \&$ isAllowed $=y$

Law of Registered Civil Societies, Registered Civil Partnership Act, Lifetime Companies Act of February 16, 2001 (BGBl. I p. 266). https://www.gesetze-im-

internet.de/lpartg/BJNR026610001.html

Law No. 52. Introducing the right to marry for persons of the same sex, Federal Law Gazette Part I/2017, 28/07/2017. https://www.bgbl.de/xaver/bgbl/start.xav?sta rtbk=Bundesanzeiger_BGB1\&start $=/ / * \% 5 \mathrm{~b}$ @attr_id=\%27bgbl117s2787.pdf\%27\%5d\#_ _bgbl_\%2F\%2F*\%5B\%40attr_id\%3D\%27 bgbl117s2787.pdf\%27\%5D_16378489089 43

Marth, Ch. (2021). Inheritance law (Austria). GlobalPropertyGuide.

https://www.globalpropertyguide.com/Europ e/Austria/Inheritance

Maslov, S. (2011). Universal Austrian Civil Code (Allgemeines Burgerliches Gesetzbuch). Moscow: Infotropic Media. ISBN 978-5-9998-0031-2

Royal Decree No. 206, of Spaniards and foreigners, Gobierno de España, July 24 of 1889.

http://www.interior.gob.es/web/servicios-alciudadano/normativa/reales-decretos/realdecreto-de-24-de-julio-de-1889

Sidenko, V.V. (2017). Testament: problematic issues under the legislation of Ukraine and foreign countries. In the collection: from Roman private law to European law of the 15th International scientific and practical conference. Odessa: Feniks. (In Ukranian)

Valakh, V. (2009). Comparative characteristic of hereditary legal relationships in Ukraine and foreign countries (the Russian Federation, France, Germany and the USA). (PhD Dissertation). Research Institute of Private Law and Enterprise of Academy of Legal Science of Ukraine. http://dspace.onu.edu.ua:8080/bitstream/123 456789/29950/1/aref.doc.pdf

Wiedermann, M. (2020). Understanding Spanish inheritance law. ABACO Advisers. https://blog.abacoadvisers.com/guide-tospanish-inheritance-law/

Zavgorodnia, I. M. (2016). Court Proceedings in cases on Controversions Arising from Inheritance Legal Relations. (PhD Dissertation). Kharkiv National University of Internal Affairs, Ukraine. http://dspace.univd.edu.ua/xmlui/bitstream/h andle/123456789/1656/rozglyad_sudami_sp rav_u_sporah_scho_vini.pdf?sequence=2\&is Allowed=y 